\title{
Molecular and biological characterization of corchorus mottle virus, a new begomovirus from Brazil
}

\author{
Rosana Blawid · Rafaela S. Fontenele • \\ Cristiano Lacorte $\cdot$ Simone G. Ribeiro
}

Received: 21 December 2012/Accepted: 5 May 2013/Published online: 29 June 2013

(c) Springer-Verlag Wien 2013

\begin{abstract}
A begomovirus infecting Orinoco jute (Corchorus hirtus) from Brazil was characterized. Molecular analysis revealed a bipartite genomic organization, which is typical of the New World begomoviruses. Sequence analysis and phylogenetic data showed that both genomic components have the closest relationship with abutilon mosaic Brazil virus, with an identity of $87.3 \%$ for DNA-A, indicating that this virus is a member of a new begomovirus species for which the name "Corchorus mottle virus" $(\mathrm{CoMoV})$ is proposed. Sida rhombifolia plants inoculated by biolistics with an infectious clone of $\mathrm{CoMoV}$ showed systemic vein chlorosis, mottling and leaf deformation symptoms, while Nicotiana benthamiana and tomato plants had symptomless infection. CoMoV is the first corchorusinfecting begomovirus reported in Brazil.
\end{abstract}

Begomoviruses are plant pathogens that cause high yield losses in many important crops worldwide [31, 33, 43]. They belong to the family Geminiviridae, which is additionally composed of six other genera, Curtovirus, Mastrevirus, Becurtovirus, Eragrovirus, Turncurtovirus, and

Electronic supplementary material The online version of this article (doi:10.1007/s00705-013-1764-x) contains supplementary material, which is available to authorized users.

R. Blawid · R. S. Fontenele · C. Lacorte · S. G. Ribeiro $(\square)$ Laboratório de Interação Planta-Praga III, Embrapa Recursos Genéticos e Biotecnologia, Pq. Estação Biológica, Brasília, DF 70770-917, Brazil

e-mail: simone@cenargen.embrapa.br;

simone.ribeiro@embrapa.br

R. Blawid · R. S. Fontenele

Departamento de Biologia Celular, Universidade de Brasília, Brasília, DF, Brazil
Topocuvirus. Begomoviruses are transmitted by the whitefly Bemisia tabaci in a circulative manner to dicots through either a bipartite or monopartite genome. Bipartite viruses have a genome consisting of two circular singlestranded DNA (ssDNA) molecules (DNA-A and DNA-B), while monopartite viruses have only one ssDNA component. Satellite molecules (alphasatellites and betasatellites) may be associated with begomoviruses, especially Old World monopartite viruses [6, 8]. Begomovirus DNA-A encodes proteins responsible for particle encapsidation (CP/ORF AV1), viral replication (Rep/ORF AC1 and Ren/ ORF AC3), regulation of gene expression, and for some viruses, suppression of gene silencing (TrAP/ORF AC2). $\mathrm{AC} 4$ has been implicated in modulation of symptom development and may also act as a suppressor of gene silencing. AV2 is only present in begomoviruses that originated in the Old World. The proteins NSP (ORF BV1) and MP (ORF BC1) located in DNA-B encode two proteins involved in intracellular and intercellular virus movement [27, 29]. The DNA-A and DNA-B components share a common region (CR) of approximately $200 \mathrm{bp}$ with high sequence identity (usually 80-100 \%) [7, 24, 30, 37]. The CR harbours a putative stem-loop structure containing the nonanucleotide TAATATT $\downarrow$ AC, which is highly conserved and functions in the initiation of the rolling-circle replication. The CR also contains cis elements (CA-, TATAand G-box) involved in the virus replication and transcription processes $[11,12]$.

In Brazil, begomoviruses are major pathogens and constraint factors for common bean and tomato production $[13,36]$. Members of different begomoviruses species have also been reported infecting weed plants belonging to the families Euphorbiaceae, Solanaceae, Compositae, Capparaceae, Fabaceae and Malvaceae [3, 9, 15, 34, 39, 40]. Weeds and wild plants are believed to serve as reservoirs 
for begomoviruses where evolutionary-driving processes such as recombination and pseudo-recombination may occur, thus making these species intermediate hosts in the adaptation process that allows these viruses to infect economically important crops [32, 36]. Characterization of viruses infecting weed plants may shed light on the evolutionary and ecological dynamics of begomoviruses. Nevertheless, little attention has been paid to these aspects or to surveying begomoviruses infecting weed plants.

Orinoco jute (Corchorus hirtus L.) is an annual malvaceous herbaceous plant native to the Americas that grows in the West Indies, the southern United States, Mexico, Central and South America [42]. In Brazil, C. hirtus is found distributed in all geographical regions, occupying the Amazon, Caatinga, Cerrado, Mata Atlântica and Pantanal phytogeographical domains [5]. In these areas, it grows either as a ruderal or an invading weed that infests pasture preferably, but it may also occur in agricultural crops such as cotton, cassava, maize and beans $[18,28]$. Begomoviruses have been isolated from different species of Corchorus collected in Mexico, Vietnam and India [16, 17, 19, 20, 23]; however, Corchorus spp. have not yet been described as begomovirus hosts in Brazil.

In this study, we report the molecular and biological characterization of a proposed new bipartite begomovirus infecting Corchorus hirtus in Brazil, which we tentatively named corchorus mottle virus (CoMoV).

A C. hirtus plant showing mottle symptoms (Fig. 1A) was collected in the vicinity of a sweet potato field in the rural area of Batateiras District, São Joaquim dos Montes, in the Northeastern state of Pernambuco, Brazil. Total DNA was extracted using a CTAB protocol [10]. PCR using primers pAL1v1978 and pAR1c496 [38] resulted in a fragment of $\sim 1.2 \mathrm{~kb}$, which was cloned in pGEM ${ }^{\circledR}-\mathrm{T}$ Easy Vector. Comparison of the sequences of eight independent clones showed 98-99\% identity among them, and BLAST search for similar sequences confirmed begomoviral infection. The viral genome was amplified by the rolling-circle amplification (RCA) method using $\Phi 29$ DNA polymerase (TempliPhi, GE Healthcare) according to Inoue-Nagata et al. [26]. RCA multimeric products were initially digested with the four-base cutter restriction enzyme MspI. The sum of the restriction fragments obtained was approximately $5.3 \mathrm{~kb}$, which is indicative of an infection with a single New World bipartite begomovirus [21]. RCA products were then digested with a set of restriction endonucleases (EcoRI, BamHI, SmaI, SacI, KpnI, XhoI and HindIII). A complete digestion of the RCA products was obtained with $K p n I$ and putative viral fulllength monomers of ca. $2.6 \mathrm{~kb}$ were cloned into the pBluescript SK+ vector linearized with the same enzyme. Five clones harboring fragments of the expected size were recovered, and digestion with $M s p$ I rendered two different restriction patterns. All recovered clones were initially sequenced with pBluescript SK+ standard primers. Since the sequences of the clones with the same restriction pattern were nearly identical over a $1.6-\mathrm{kb}$ sequence fragment (99\% identity), the clones $62 \mathrm{~K} 2$ and $62 \mathrm{~K} 3$ were chosen as representative of DNA-A and DNA-B, respectively, and fully sequenced by primer walking (Macrogen Inc., South
Fig. 1 Symptoms induced by natural or experimental $\mathrm{CoMoV}$ infection. (A) Mottling in a naturally infected Corchorus hirtus plant. (B) Diffuse local chlorotic lesions in inoculated leaves of Sida glasiovii at 10 days post-inoculation (dpi). (C) Chlorotic local spots and diffuse local chlorotic lesions in S. rhombifolia at $10 \mathrm{dpi}$.

(D) Vein chlorosis, mottling and leaf deformation in $S$. rhombifolia at $22 \mathrm{dpi}$
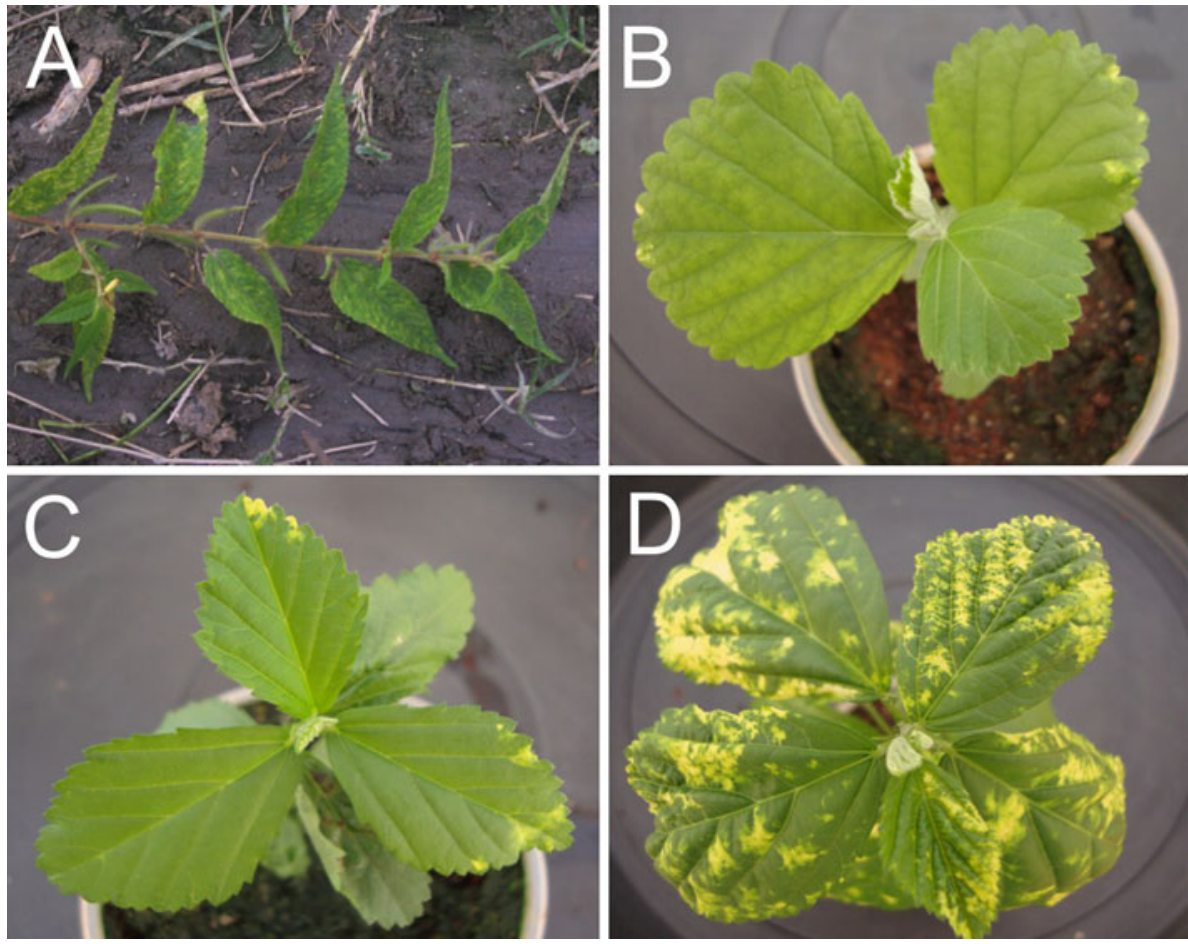
Korea). Contigs were assembled using the Sequence Assembly function of the DNAMAN program (Lynnon Corporation).

Nucleotide sequences of clones $62 \mathrm{~K} 2$ and $62 \mathrm{~K} 3$ were analyzed by BLAST to search for sequence similarity with other begomoviruses and for preliminary species assignment. The ClustalV algorithm (with default parameters) implemented in the MegAlign software (DNASTAR, WI, USA) was used for multiple sequence alignment and pairwise comparisons [14]. Phylogenetic analysis and tree graphics were generated by Mega v.5 (maximum-likelihood method, 1000 bootstrap replicates) [41]. Promoter analysis was performed using GPMiner (http://gpminer. mbc.nctu.edu.tw/index.php).

DNA-A of CoMoV is 2650 nucleotides in length with a genomic structure characteristic of begomoviruses from the New World. Pairwise comparison with other begomoviruses showed highest identity $(87.3 \%)$ to abutilon mosaic Brazil virus (AbMBV-[BR:BA]) [35]. According to the current demarcation threshold for begomovirus species ( $<89 \%$ identity for DNA-A) recommended by the Geminiviridae Study Group of the International Committee on Taxonomy of Viruses [14], CoMoV should be regarded as a member of a tentative new bipartite begomovirus species.

The intergenic region of $\mathrm{CoMoV}-\mathrm{A}$ consisted of $250 \mathrm{bp}$, containing several cis-acting elements, including TATA boxes and CAA repeats typically found in begomoviruses. Using tools available in GPMiner, three TATA motifs were found at positions 2522-2527, 2594-2597 and 199-202, one CCAAT box (GCCAAT) was predicted at position 128-133, and one GC box (GGCGGC) was found at position 45-50.

The complete nucleotide sequence of clone of $62 \mathrm{~K} 3$, which represents the $\mathrm{B}$ component of $\mathrm{CoMoV}$, consisted of $2611 \mathrm{bp}$, with greatest nucleotide sequence identity (66.6 $\%)$ to AbMBV-[BR:BA]-DNA-B.

Detailed nucleotide (nt) and deduced amino acid (aa) sequence comparisons between $\mathrm{CoMoV}$ and closely related and corchorus-infecting begomovirus sequences are presented in Table 1. As expected, the highest degree of identity of CoMoV genes was with AbMBV-[BR:BA], except for the AC2 nt sequence, which had highest identity $(88.1 \%)$ to $\mathrm{AC} 2$ of tomato common mosaic virus (ToCMMV-[BR:Coi22:07]-EU710754) [9]. With the exception of the CoMoV-AV1-derived aa sequence, which had the highest similarity score of $96.4 \%$ with the CP of tomato leaf distortion virus (ToLDV-[BR:Pda4:05]-EU710749) [9], all other protein sequences were more similar to those of AbMBV-[BR:BA]. For DNA-B, BV1 had the highest sequence identity for both nt and aa to AbMBV-[BR:BA]. For BC1, the maximum nt sequence identity was with sida mosaic Brazil virus-[BR], while the derived aa sequence had highest similarity to that of abutilon mosaic Brazil
virus-[BR:BA]. An incongruent nucleotide sequence identity for different segments of the viral genome may be indicative of a recombinant origin. However, further studies are needed to verify if there were any recombination events involving $\mathrm{CoMoV} \mathrm{AC} 2$ and $\mathrm{BC} 1$ to confirm a possible recombinant nature of $\mathrm{CoMoV}$.

CoMoV DNA-A and DNA-B intergenic regions share a common region (CR) of 189 bp with an identity of $89.4 \%$. This identity score is more divergent than what is commonly observed for CRs of a cognate pair of DNA-A and DNA-B. However, similar and even lower CR identity scores have several precedents in the literature $[7,22,24$, 25, 30]. The CoMoV CR contains the geminivirus conserved nonanucleotide sequence (TAATATT $\downarrow$ AC) and two core iteron [1] sequences, GGAGTCC and GGACTCC.

Although CoMoV and the closely related AbMBV[BR:BA] share the same iterons, the number and position of the iterated sequences differ between the two viruses. Whereas $\mathrm{CoMoV}$ iterons were found four times upstream of the TATA box in DNA-A, five times in DNA-B, and once downstream of the TATA box in both components, in the AbMBV-[BR:BA] CR, the iterons are present four times in both DNA-A and DNA-B, only downstream of the TATA box (Supplementary Figure S1). Interestingly, because of their partially palindromic sequence, the iteron repeats can be perceived either as direct or inverted repeats (Supplementary Figure S1).

Phylogenetic maximum-likelihood trees were constructed using a multiple alignment of selected bipartite New World and corchorus-infecting begomoviruses. CoMoV and AbMBV DNA-A are sister taxa in a group that also includes sida yellow leaf curl virus (SiYLCV) and ToCMMV from Brazil. This group clusters along a large group of viruses isolated from weed and crop plants, mainly from Mexico and the USA, in agreement with previous reports [9, 35] (Fig. 2). CoMoV DNA-B also clustered with other begomoviruses from Brazil, but in contrast to DNA-A, it was more distantly related to the DNA-B of AbMBV (Fig. 2). These results are in accordance with the pairwise sequence identity data (Table 1). No close relationship was found between CoMoV and other corchorus-infecting viruses reported from Mexico, India or Vietnam [19, 20, 23].

For infectivity tests and partial host range determination, single copies of DNA-A and DNA-B genomes were released from the $K p n \mathrm{I}$ site of pBluescript $\mathrm{SK}^{+}$vector and self-ligated as described [37]. For particle bombardment inoculation, DNA $(2.5 \mu \mathrm{g})$ of each component was combined and precipitated with $3.0 \mathrm{mg}$ of tungsten particles (M10). Plants showing one to two fully expanded true leaves were placed in a helium-driven particle bombardment device, at a distance of $2-5 \mathrm{~cm}$ from the macrocarrier, which was launched by a helium discharge of 850 PSI, in a 
A

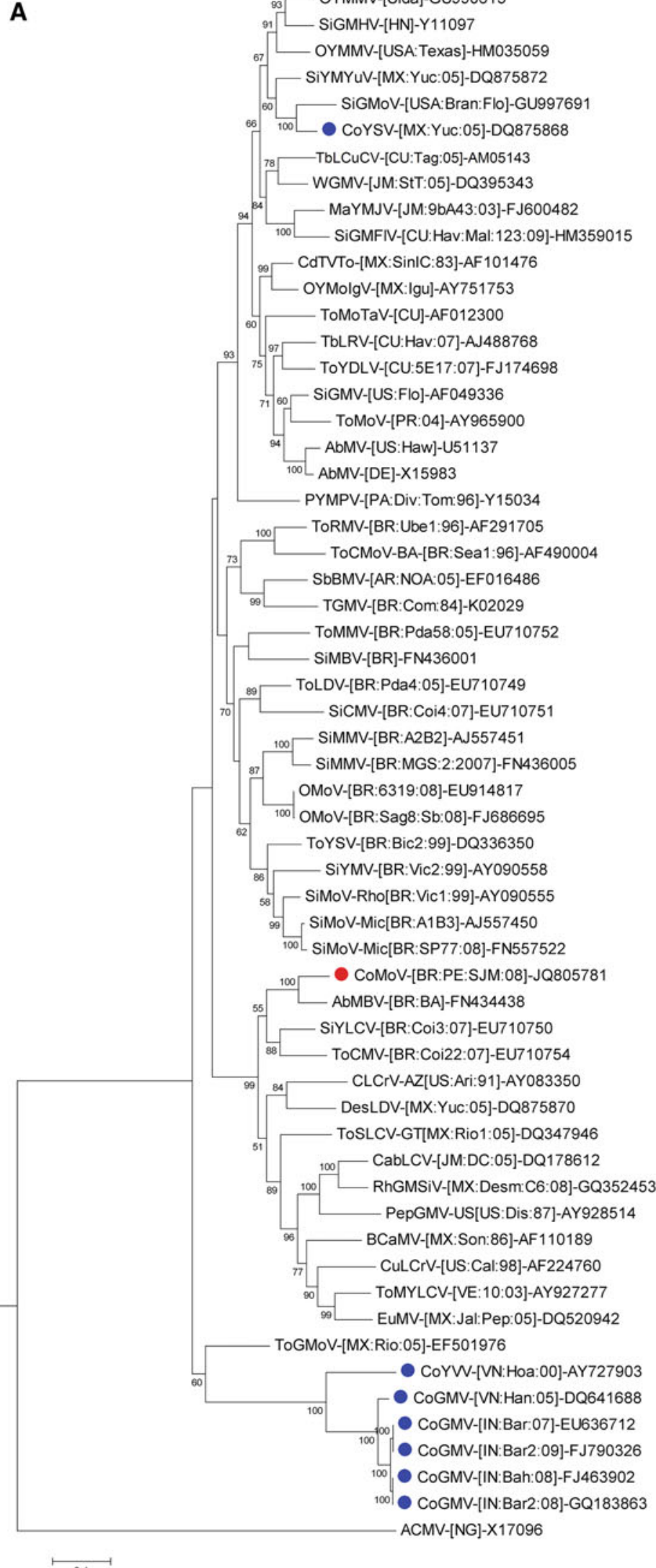

B

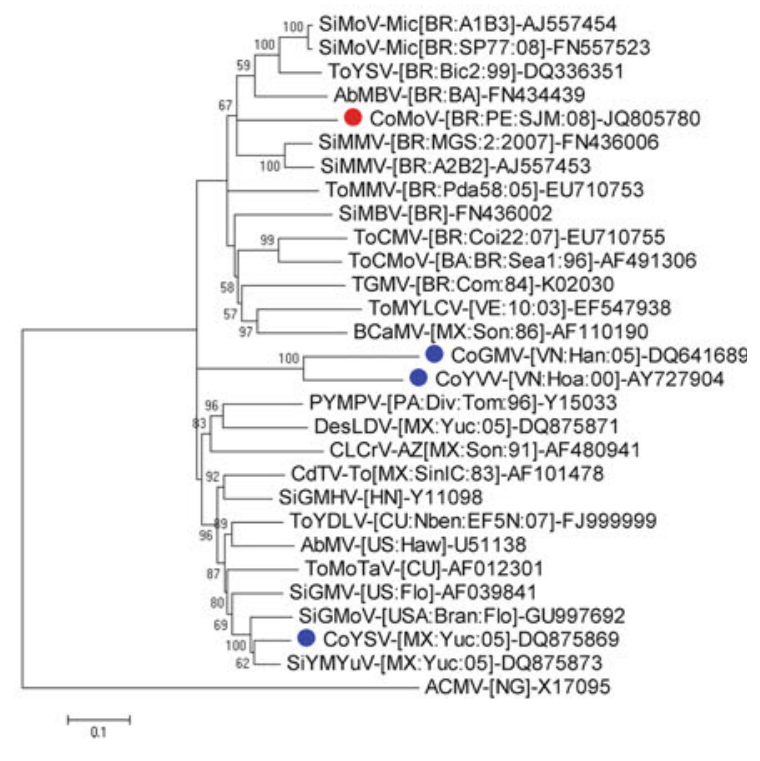


4Fig. 2 Maximum-likelihood phylogenetic trees based on complete DNA-A (A) and DNA-B (B) alignments of selected New World and corchorus-infecting begomoviruses. Bootstrap scores above $50 \%$ (1000 replicates) are placed at the tree nodes. Genomic component sequences of an African cassava mosaic virus (ACMV) isolate were used as outgroups. Red dot indicates CoMoV; and blue dots, sequences from other corchorus-infecting viruses. The scale bar represents the number of nucleotide substitutions per site. Accession numbers are placed beside the virus name abbreviation. Supplementary Table S2 shows virus names and acronyms used throughout this paper vacuum chamber (25 inHg). Immediately after, inoculated plants were placed in a humid chamber for 2 days and then transferred to whitefly-proof cages and kept in a greenhouse at $19-28{ }^{\circ} \mathrm{C}$. Eight plants of each tested host species (Nicotiana benthamiana, Sida glaziovii, S. rhombifolia, S. cordifolia and Solanum lycopersicum) were inoculated. Mock-inoculated plants were used as negative controls. Symptoms were recorded, and total DNA was extracted 22 days post-inoculation (dpi). CoMoV infection was

Table 1 Nucleotide (nt) and deduced amino acid (aa) sequence identities (\%) between corchorus mottle virus and other selected begomoviruses

\begin{tabular}{|c|c|c|c|c|c|c|c|c|c|c|c|}
\hline \multirow[t]{2}{*}{ Virus } & \multicolumn{11}{|c|}{ Genomic region } \\
\hline & DNA-A & DNA-B & $\mathrm{IR}^{\mathrm{a}}$ & & AV1 & AC3 & AC2 & $\mathrm{AC} 1$ & AC4 & BV1 & $\mathrm{BC} 1$ \\
\hline \multirow[t]{2}{*}{ Abutilon mosaic Brazil virus-[BR:BA] } & $87.3^{\mathrm{b}}$ & $66.6^{\mathrm{b}}$ & $84.9^{\mathrm{b}}$ & nt & $89.4^{\mathrm{b}}$ & $90.2^{\mathrm{b}}$ & 87.7 & $87.6^{b}$ & $90.3^{\mathrm{b}}$ & $78.5^{\mathrm{b}}$ & 75.7 \\
\hline & & & & aa & 95.6 & $\mathbf{8 8 . 6}^{\mathrm{b}}$ & $85.3^{\mathrm{b}}$ & $90.4^{\mathrm{b}}$ & $78.6^{\mathrm{b}}$ & $82.8^{b}$ & $84.6^{\mathrm{b}}$ \\
\hline \multirow[t]{2}{*}{ Sida yellow leaf curl virus-[BR:Coi3:07] } & 78.3 & $\mathrm{n} \cdot \mathrm{a}^{\mathrm{c}}$ & 62.6 & $\mathrm{nt}$ & 84.8 & 88.2 & 85.9 & 76.8 & 77.3 & n.a & n.a \\
\hline & & & & aa & 93.6 & 84.8 & 80.6 & 81.7 & 56.5 & & \\
\hline \multirow[t]{2}{*}{ Tomato common mosaic virus-[BR:Coi22:07] } & 77.8 & 55.6 & 61.8 & $\mathrm{nt}$ & 80.3 & 86.5 & $88.1^{\mathrm{b}}$ & 77.9 & 75.7 & 66.3 & 70.2 \\
\hline & & & & aa & 90.4 & 87.1 & 79.7 & 83.7 & 54.4 & 69.1 & 82.3 \\
\hline \multirow[t]{2}{*}{ Desmodium leaf distortion virus-[MX:Yuc:05] } & 74.2 & 54.0 & 46.7 & $\mathrm{nt}$ & 81.7 & 79.2 & 73.8 & 76.1 & 80.1 & 64.1 & 72.0 \\
\hline & & & & aa & 90.4 & 81.1 & 67.4 & 80.9 & 59.5 & 68.0 & 81.2 \\
\hline \multirow[t]{2}{*}{ Tomato leaf distortion virus-[BR:Pda4:05] } & 73.9 & n.a & 61.8 & nt & 87.7 & 87.7 & 85.1 & 63.8 & 45.5 & n.a & n.a \\
\hline & & & & aa & $96.4^{\mathrm{b}}$ & 87.1 & 80.6 & 64.0 & 25.3 & & \\
\hline \multirow[t]{2}{*}{ Tomato severe leaf curl virus-GT[MX:Rio1:05] } & 72.3 & n.a & 39.9 & nt & 82.1 & 75.7 & 71.8 & 75.1 & 78.7 & n.a & n.a \\
\hline & & & & aa & 92.8 & 75.8 & 58.6 & 81.0 & 62.0 & & \\
\hline \multirow[t]{2}{*}{ Euphorbia mosaic virus-B[MX:Jal:Pep:05] } & 72.1 & n.a & 41.4 & $\mathrm{nt}$ & 79.0 & 72.4 & 71.3 & 77.1 & 74.6 & n.a & n.a \\
\hline & & & & aa & 92.4 & 73.5 & 65.1 & 83.4 & 58.4 & & \\
\hline \multirow[t]{2}{*}{ Sida mottle virus-Rho[BR:Vic1:99] } & 70.2 & n.a & 57.4 & nt & 86.6 & 88.2 & 87.9 & 60.8 & 49.2 & n.a & n.a \\
\hline & & & & aa & 93.6 & 87.1 & 83.7 & 59.3 & 25.6 & & \\
\hline \multirow[t]{2}{*}{ Sida mottle virus - Mic[BR:SP77:08] } & 70.3 & 54.5 & 51.3 & nt & 83.6 & 88.0 & 85.9 & 64.04 & 42.0 & 77.3 & 75.4 \\
\hline & & & & aa & 92.8 & 84.1 & 82.9 & 65.2 & 23.1 & 80.1 & 80.9 \\
\hline \multirow[t]{2}{*}{ Sida mottle virus-Mic[BR:A1B3] } & 70.5 & 55.0 & 51.3 & $\mathrm{nt}$ & 84.8 & 88.5 & 86.2 & 63.9 & 45.0 & 73.0 & 71.3 \\
\hline & & & & aa & 93.6 & 84.1 & $85.3^{\mathrm{b}}$ & 64.6 & 20.0 & 79.3 & 80.2 \\
\hline \multirow[t]{2}{*}{ Tomato yellow spot virus-[BR:Bic2:99] } & 70.4 & 55.7 & 49.5 & $\mathrm{nt}$ & 83.7 & 86.7 & 84.4 & 61.7 & 45.0 & 72.0 & 72.0 \\
\hline & & & & aa & 92.8 & 84.8 & 80.6 & 63.2 & 25.9 & 77.3 & 79.2 \\
\hline \multirow[t]{2}{*}{ Sida mosaic Brazil virus-[BR] } & 69.7 & 57.9 & 55.4 & nt & 84.5 & 83.5 & 79.7 & 60.1 & 43.0 & 67.4 & $76.1^{b}$ \\
\hline & & & & aa & 94.4 & 83.3 & 73.6 & 63.2 & 17.6 & 72.7 & 84.0 \\
\hline \multirow[t]{2}{*}{ Corchorus yellow spot virus-[MX:Yuc:05] } & 68.8 & 51.3 & 50.9 & $\mathrm{nt}$ & 83.1 & 83.7 & 75.1 & 61.0 & 45.8 & 62.9 & 72.6 \\
\hline & & & & aa & 92.8 & 84.8 & 69.8 & 62.1 & 26.4 & 67.6 & 82.6 \\
\hline \multirow[t]{2}{*}{ Sida micranta mosaic virus-[BR:MGS:2:2007] } & 68.7 & 55.5 & 50.3 & $\mathrm{nt}$ & 85.2 & 85.2 & 83.6 & 59.8 & 45.7 & 72.0 & 72.2 \\
\hline & & & & aa & 94.8 & 84.8 & 80.6 & 61.8 & 23.5 & 79.3 & 82.9 \\
\hline \multirow[t]{2}{*}{ Sida yellow mosaic virus-[BR:Vic2:99] } & 65.7 & n.a & 55.1 & $\mathrm{nt}$ & 83.5 & 85.7 & 83.8 & 61.3 & 43.4 & n.a & n.a \\
\hline & & & & aa & 86.9 & 73.5 & 71.3 & 60.1 & 22.4 & & \\
\hline \multirow[t]{2}{*}{ Corchorus golden mosaic virus-[VN:Han:05] } & 51.8 & 42.3 & 22.8 & nt & 74.7 & 54.2 & 51.8 & 46.0 & 36.6 & 47.4 & 62.2 \\
\hline & & & & aa & 86.3 & 44.6 & 44.2 & 45.2 & 18.0 & 51.8 & 71.9 \\
\hline \multirow[t]{2}{*}{ Corchorus yellow vein virus-[VN:Hoa:00] } & 50.1 & 42.9 & 25.3 & nt & 75.9 & 53.7 & 51.5 & 45.0 & 41.2 & 51.3 & 62.1 \\
\hline & & & & aa & 86.9 & 46.2 & 47.3 & 45.5 & 16.7 & 54.5 & 74.0 \\
\hline
\end{tabular}

\footnotetext{
a The intergenic region (IR) sequence is derived from DNA- A

${ }^{b}$ Maximum identities are in bold

c n.a: not available
} 
Table 2 Experimental hosts and symptoms displayed by plants inoculated by particle bombardment with $\mathrm{CoMoV}$ clones

\begin{tabular}{lll}
\hline Host plant & Infectivity $^{\mathrm{a}}$ & Symptoms $^{\mathrm{b}}$ \\
\hline Sida rhombifolia & $8 / 8$ & $\mathrm{CS}, \mathrm{VC}, \mathrm{Mo}, \mathrm{LD}$ \\
Sida glaziovii & $1 / 8$ & LCS \\
Sida cordifolia & $0 / 8$ & $\mathrm{NI}$ \\
Solanum lycopersicum & $4 / 8$ & SI \\
'Santa Clara' & & \\
Nicotiana benthamiana & $8 / 8$ & SI \\
\hline
\end{tabular}

${ }^{a}$ Number of infected plants /number of inoculated plants

${ }^{\text {b }}$ CS, chlorotic spots; LCS, local chlorotic spots; LD, leaf deformation; Mo, mottle; VC, veinal chlorosis; SI, symptomless infection; NI, no infection

confirmed by amplifying and sequencing virus fragments with primers PAL1v1978 and PAR1c496 [38].

A range of plants proved to be experimental hosts of CoMoV (Table 2). All S. rhombifolia plants initially showed very small chlorotic spots, which evolved to larger and more diffuse spots by 10 dpi (Fig. 1C). At 22 dpi, extensive vein chlorosis, mottling and leaf deformation could be observed (Fig. 1D). In one of the eight inoculated S. glaziovii, similar diffused local chlorotic spots could be seen in inoculated leaves, and the virus could be PCRamplified from DNA extracted from these lesions (Fig. 1B). However, the infection did not spread, and the virus could not be recovered from new, non-symptomatic leaves. Although none of the $N$. benthamiana or tomato plants showed symptoms, CoMoV fragments could be amplified from systemic non-inoculated leaves from the eight $N$. benthamiana and four tomato plants that were inoculated. S. cordifolia plants did not become infected by CoMoV.

Transmission of weed-infecting Brazilian begomoviruses to crop plants such as tomato by grafting and/or biolistics has been reported previously [2, 4, 34]. Although present at high titers in the weed host, usually these viruses are poorly transmitted to tomatoes, and symptoms are milder or absent, as in the case of CoMoV-infected tomato plants. Barreto et al. [4] suggest that viruses originating from weeds are less adapted to tomatoes. Nevertheless, viruses such as CoMoV may pose a potential threat to crop plants, since adaptation to the cultivated host may occur by mutation, recombination or pseudo-recombination and emerge as a new tomato disease.

Acknowledgments This work was financed in part by grants from Embrapa and CNPq (INCTIPP). RB and RSF were supported by fellowships from CNPq. We thank Arnildo Pott and José Francisco Montenegro Valls for taxonomic identification of the Corchorus hirtus plant, and Pedro Henrique de Souza for greenhouse assistance.

\section{References}

1. Arguello-Astorga GR, Guevara-Gonzalez RG, Herrera-Estrella LR, Rivera-Bustamante RF (1994) Geminivirus replication origins have a group-specific organization of iterative elements: a model for replication. Virology 203:90-100

2. Arnaud LSEP, Santos CDG, Lima JAA, Feitosa FAA (2007) Predominância de begomovírus em tomateiros na região produtora da Ibiapaba, Ceará, e sua detecção natural em plantas daninhas. Fitopatol Bras 32:241-246

3. Barbosa JC, Barreto SS, Inoue-Nagata AK, Reis MS, Firmino AC, Bergamin A, Rezende JAM (2009) Natural infection of Nicandra physaloides by Tomato severe rugose virus in Brazil. J Gen Plant Pathol 75:440-443

4. Barreto S, Hallwas M, Aquino O, Inoue-Nagata AK (2013) A study of weeds as potential inoculum sources for atomato-infecting begomovirus in Central Brazil. Phytopathology 103:436-444

5. Bovini MG (2010) Corchorus Lista de Espécies da Flora do Brasil. Jardim Botânico do Rio de Janeiro, Rio de Janeiro

6. Briddon RW, Stanley J (2006) Subviral agents associated with plant single-stranded DNA viruses. Virology 344:198-210

7. Brown JK, Idris AM, Ostrow KM, Goldberg N, French R, Stenger DC (2005) Genetic and phenotypic variation of the pepper golden mosaic virus complex. Phytopathology 95:1217-1224

8. Brown JK, Fauquet CM, Briddon RW, Zerbini M, Moriones E, Navas-Castillo J (2012) Family Geminiviridae. In: King AMQ, Adams MJ, Carstens EB, Lefkowitz E (eds) Virus Taxonomy: Ninth Report of the International Committee on Taxonomy of Viruses. Elsevier Academic Press, San Diego, pp 351-373

9. Castillo-Urquiza GP, Beserra JE Jr, Bruckner FP, Lima AT, Varsani A, Alfenas-Zerbini P, Murilo Zerbini F (2008) Six novel begomoviruses infecting tomato and associated weeds in Southeastern Brazil. Arch Virol 153:1985-1989

10. Doyle JJ, Doyle JL (1987) A rapid isolation procedure for small quantities of fresh leaf tissue. Phytochem Bull 19:11-15

11. Eagle PA, Orozco BM, Hanley-Bowdoin L (1994) A DNA sequence required for geminivirus replication also mediates transcriptional regulation. Plant Cell 6:1157-1170

12. Eagle PA, Hanley-Bowdoin L (1997) Cis Elements that contribute to geminivirus transcriptional regulation and the efficiency of DNA replication. J Virol 71:6947-6955

13. Faria JC, Bezerra IC, Zerbini FM, Ribeiro SG, Lima MF (2000) Situação atual das geminiviroses no Brasil. Fitopatol Bras 25:125-137

14. Fauquet CM, Briddon RW, Brown JK, Moriones E, Stanley J, Zerbini M, Zhou X (2008) Geminivirus strain demarcation and nomenclature. Arch Virol 153:783-821

15. Fernandes FR, Albuquerque LC, Oliveira CL, Cruz AR, Rocha WB, Pereira TG, Naito FY, Dias NM, Nagata T, Faria JC, Zerbini FM, Aragao FJ, Inoue-Nagata AK (2011) Molecular and biological characterization of a new Brazilian begomovirus, euphorbia yellow mosaic virus (EuYMV), infecting Euphorbia heterophylla plants. Arch Virol 156:2063-2069

16. Ghosh R, Paul S, Das S, Palit P, Acharyya S, Das A, Mir J, Ghosh S, Roy A (2008) Molecular evidence for existence of a New World begomovirus associated with yellow mosaic disease Corchorus capsularis in India. Australas Plant Dis Notes 3:59-62

17. Ghosh R, Palit P, Paul S, Ghosh SK, Roy A (2012) Detection of Corchorus golden mosaic virus associated with yellow mosaic disease of jute (Corchorus capsularis). Indian J Virol 23:70-74

18. Guglieri-Caporal A, Caporal FJM, Pott A (2010) Phytosociology of sown pasture weeds under two levels of degradation in Brazilian savanna areas, Mato Grosso do Sul State, Brazil. Pesquisa Agropecuária Tropical 40:312-321 
19. Ha C, Coombs S, Revill P, Harding R, Vu M, Dale J (2006) Corchorus yellow vein virus, a New World geminivirus from the Old World. J Gen Virol 87:997-1003

20. Ha C, Coombs S, Revill P, Harding R, Vu M, Dale J (2008) Molecular characterization of begomoviruses and DNA satellites from Vietnam: additional evidence that the New World geminiviruses were present in the Old World prior to continental separation. J Gen Virol 89:312-326

21. Haible D, Kober S, Jeske H (2006) Rolling circle amplification revolutionizes diagnosis and genomics of geminiviruses. J Virol Methods 135:9-16

22. Harimalala M, Lefeuvre $\mathrm{P}$, De Bruyn A, Tiendrebeogo F, Hoareau M, Villemot J, Ranomenjanahary S, Andrianjaka A, Reynaud B, Lett JM (2012) A novel cassava-infecting begomovirus from Madagascar: cassava mosaic Madagascar virus. Arch Virol 157:2027-2030

23. Hernandez-Zepeda C, Idris AM, Carnevali G, Brown JK, Moreno-Valenzuela OA (2007) Molecular characterization and phylogenetic relationships of two new bipartite begomovirus infecting malvaceous plants in Yucatan, Mexico. Virus Genes 35:369-377

24. Hill JE, Strandberg JO, Hiebert E, Lazarowitz SG (1998) Asymmetric infectivity of pseudorecombinants of cabbage leaf curl virus and squash leaf curl virus: Implications for bipartite geminivirus evolution and movement. Virology 250:283-292

25. Idris AM, Brown JK (2005) Cotton leaf crumple virus Is a distinct Western Hemisphere begomovirus species with complex evolutionary relationships indicative of recombination and reassortment. Phytopathology 94:1068-1074

26. Inoue-Nagata AK, Albuquerque LC, Rocha WB, Nagata T (2004) A simple method for cloning the complete begomovirus genome using the bacteriophage phi29 DNA polymerase. J Virol Methods 116:209-211

27. Jeske H (2009) Geminiviruses. Curr Top Microbiol Immunol 331:185-226

28. Kissmann KG, Groth D (1995) Plantas infestantes e nocivas, 1st edn. BASF, São Paulo

29. Lazarowitz SG (1992) Geminiviruses: genome structure and gene function. Crit Rev Plant Sci 11:327-349

30. Marquez-Martin B, Maeso D, Martinez-Ayala A, Bernal R, Teresa Federici M, Vincelli P, Navas-Castillo J, Moriones E (2012) Diverse population of a new bipartite begomovirus infecting tomato crops in Uruguay. Arch Virol 157:1137-1142

31. Morales FJ, Anderson PK (2001) The emergence and dissemination of whitefly-transmitted geminiviruses in Latin America. Arch Virol 146:415-441
32. Mubin M, Briddon RW, Mansoor S (2009) Diverse and recombinant DNA betasatellites are associated with a begomovirus disease complex of Digera arvensis, a weed host. Virus Res 142:208-212

33. Navas-Castillo J, Fiallo-Olive E, Sanchez-Campos S (2011) Emerging virus diseases transmitted by whiteflies. Annu Rev Phytopathol 49:219-248

34. Paprotka T, Metzler V, Jeske H (2010) The first DNA 1-like alpha satellites in association with New World begomoviruses in natural infections. Virology 404:148-157

35. Paprotka T, Metzler V, Jeske H (2010) The complete nucleotide sequence of a new bipartite begomovirus from Brazil infecting Abutilon. Arch Virol 155:813-816

36. Ribeiro SG, Ambrozevícius LP, De Avila AC, Bezerra IC, Calegario RF, Fernandes JJ, Lima MF, Mello RN, Rocha H, Zerbini FM (2003) Distribution and genetic diversity of tomatoinfecting geminiviruses in Brazil. Arch Virol 148:281-295

37. Ribeiro SG, Martin DP, Lacorte C, Simões IC, Orlandini DRS, Inoue-Nagata AK (2007) Molecular and biological characterization of tomato chlorotic mottle virus suggests that recombination underlies the evolution and diversity of Brazilian tomato begomoviruses. Phytopathology 97:702-711

38. Rojas MR, Gilbertson RL, Russell DR, Maxwell DP (1993) Use of degenerate primers in the polymerase chain reaction to detect whitefly-transmitted geminiviruses. Plant Dis 77:340-347

39. Silva SJC, Castillo-Urquiza GP, Hora-Junior BT, Assuncao IP, Lima GSA, Pio-Ribeiro G, Mizubuti ESG, Zerbini FM (2011) High genetic variability and recombination in a begomovirus population infecting the ubiquitous weed Cleome affinis in Northeastern Brazil. Arch Virol 156:2205-2213

40. Silva SJC, Castillo-Urquiza GP, Hora Junior BT, Assunção IP, Lima GSA, Pio-Ribeiro G, Mizubuti ESG, Zerbini FM (2012) Species diversity, phylogeny and genetic variability of begomovirus populations infecting leguminous weeds in northeastern Brazil. Plant Pathol 61:457-467

41. Tamura K, Peterson D, Peterson N, Stecher G, Nei M, Kumar S (2011) MEGA5: molecular evolutionary genetics analysis using maximum likelihood, evolutionary distance, and maximum parsimony methods. Mol Biol Evol 28:2731-2739

42. USDA (2012) Germplasm Resources Information Network (GRIN) [Online Database]. In: ARS NGRP (ed) National Germplasm Resources Laboratory, Beltsville, Maryland

43. Varma A, Malathi VG (2003) Emerging geminivirus problems: a serious threat to crop production. Ann Appl Biol 142:145-164 